\title{
A Nexus among Strategic Orientation, Social Network, Knowledge Sharing, Organizational Innovation, and MSMEs Performance
}

\author{
Muafi MUAFI ${ }^{1}$
}

Received: February 28, 2020 Revised: March 15, 2020 Accepted: May 07, 2020

\begin{abstract}
This study wants to test the nexus among resource orientation, market orientation, social network, and knowledge sharing toward organizational innovation, and the nexus between organizational innovation and MSMEs performance. Questionnaires and interviews are conducted with some MSMEs actors in Central Java Province, Indonesia, in Klaten Regency and Pekalongan City. These two areas have creative MSMEs, especially Batik MSMEs that have been very large and known worldwide. The sampling technique is done purposively with certain criteria for the respondents. The data analysis technique is done using Partial Least Square. This study provides recommendations about strategic practice and policy (resource and market), social network, and knowledge sharing in increasing organizational innovation, and the impact of organizational innovation toward MSMEs performance. It also offers a comprehensive model of the determinant factor of organizational innovation by considering the aspect of strategic orientation, social network, and knowledge sharing. Other unique aspects that are also important to consider are social network and the importance of knowledge sharing in improving MSMEs Performance. The respondents are still limited in two areas, namely, Pekalongan and Klaten, so it still cannot represent the whole population. These areas also have different orientation of production process approach, namely, synthetic and natural dyes.
\end{abstract}

Keywords : Strategic Orientation, Social Network, Knowledge Sharing, Organizational Innovation, MSMEs Performance

JEL Classification Code: D8, L1, L2, L22.

\section{Introduction}

One of the missions of the Ministry of Cooperatives and SMEs in Indonesia (MSMEs, 2018) is implementing national security that is able to maintain regional sovereignty, sustain economic independence by securing maritime resources, and reflect the personality of Indonesia as an archipelago nation. The strategic target is to have healthy, strong, tough, and independent MSMEs to contribute to national economy. Therefore, the organizational performance of MSMEs must be resilient in a long term in order to secure long-

${ }^{1}$ First Author and Corresponding Author. Professor, Department of Management, Business and Economics Faculty, Universitas Islam Indonesia [Postal Address: Jl. SWK Ringroad Utara Condong Catur, Yogyakarta, 55283, Indonesia]

Email: muafi@uii.ac.id

(c) Copyright: The Author(s)

This is an Open Access article distributed under the terms of the Creative Commons Attribution Non-Commercial License (http://Creativecommons.org/licenses/by-nc/4.0/) which permits unrestricted noncommercial use, distribution, and reproduction in any medium, provided the original work is properly cited. term competitiveness. MSMEs in Indonesia are directed to be able to widen employment opportunities and equitable distribution of income, encourage economic growth and alleviate poverty, as well as become professional and have high levels of performance. MSMEs performance will be secure if it is supported by the role of strategic orientation, social network, knowledge sharing, and organizational innovation.

Today, the government of Indonesia is committed to increase the competitiveness and independence of the industry through Industry 4.0, including Batik (Ministry of Industry, 2017). One of the Batik mainstay areas is Pekalongan City and Klaten in Central Java Province. This city has a Batik industry that is spread all over the region and known as a worldwide Batik city. In order to be in Industry 4.0, the Batik industry in Pekalongan City and Klaten must have the right strategic orientation, therefore it can increase the organizational innovation and organizational performance. Strategic orientation is a group of value that consistently becomes the strategic guide for company in responding the uncertainty of the environment faced by the company (Matsuno, 2015; Bodea \& Dutu, 2016). 
So far, it is known that strategic orientation of the company depends on what it wants to achieve. Companies with strong customer orientation will emphasize the creation and maintenance of their customer value. It will be different if the companies are more focused on their competitor, because they will push a deep assessment to the targeted competitors. If the companies are cost-oriented, they will pursue efficiency in all their value chain (Kumar et al., 2012). In maintaining a competitive advantage, companies will spend optimal effort to manage the capital cost in order to be able to develop new service innovation (Hertog et al., 2010; Aujirpongpan \& Hareebin, 2020), and must try to understand behavioral and social element to classify SCO (supply chain orientation) individually and organizationally so that the company can operate efficiently (Lee \& Nam, 2016; Sillanpää, 2015). While resource-oriented companies will be able to increase radical innovation, so that they can develop unique resources and find environment opportunity that can be exploited (Reulink, 2012), beside needing to consider leadership, management, and entrepreneurial orientation aspects (Isada \& Isada, 2017; Shih, 2018).

The strategic orientation of the company toward the market can be described as strategic direction run by company to create the proper behavior in the increase of continuous superior performance (Isada \& Isada, 2017; Shih, 2018). Similarly, strategic orientation that is focused on customers are organizational culture that facilitates the understanding of targeted buyers and possible continuous creation of customer value (Wirtz \& Daiser, 2018; Khadka \& Maharjan, 2017), and benefits chosen by customers (Sakyi-Gyinae \& Holmlund, 2018). MSMEs that are oriented toward customers realize who their customers are and how they should be served. When they learn about customers' needs, they quickly share new information with other individuals and departments in the organization to ensure that the company can continue to respond to their customers' needs and anticipate future needs (Khadka \& Maharjan, 2017; Wirtz \& Daiser, 2018). In order to be able to grow and develop in the future, MSMEs need to strengthen their social network (Aryobsei, 2015; Muller \& Perres, 2019; Kim \& Lee, 2018) and have a strong will to share knowledge (Cerchione et al., 2015; Hussain et al., 2019).

Some research has proven that strategic orientation can increase organizational innovation and marketing performance (Obeidat, 2016). In the MSMEs field, findings from Reulink (2012) indicate that strategic orientation has an influence on innovation performance. If Batik MSMEs in Pekalongan and Klaten do not have a strategic orientation that is right on target, it is feared it will have an impact on the decrease in organizational innovation and performance. Social network (Aryobsei, 2015; Muller \&
Perres, 2018; Kim \& Lee, 2018) and knowledge sharing are very important, and both can have a significant effect on the increase of organizational innovation (Charterina \& Landeta. 2013; Cerchione et al., 2015; Hussain et al., 2019). This research wants to fill a research gap in understanding the relation between strategic orientation (resource and market orientation), social network, and knowledge sharing related to organizational innovation and MSMEs performance in Indonesia.

\section{Literature Review}

\subsection{Strategic Orientation, Organizational Innovation, and Organizational Performance}

Strategic orientation can be explained in various ways as strategic choice, strategic trust, strategic fit, strategic predisposition, and strategic design (Chaffee, 1985). Morgan and Strong (1998) explained that strategic orientation has been tested from three main points of view: narrative approach, classification approach, and comparative approach. Narrative approach utilizes qualitative methodology that often uses case study analysis. Classification approach borrows from group strategy in certain conceptual basis or certain categorization (McKelvey, 1975). Whereas, the comparative approach tries to identify and measure key characteristics of the strategy (Muafi et al., 2019).

Hakala (2011), Espino-Rodríguez and Ramírez-Fierro (2018), and Huang and Ngoc (2019) also defined strategic orientation as organization principles that can be used to drive and control organization activities that have a strong correlation with resource allocation and business opportunity faced by the company. The empirical results also proved that companies in the same industry group are not always responding to operation environment in the same way (Garcia-Pont \& Nohria, 2002). Other parties can adopt more independent attitude that consists of many approaches, such as stronger emphasize on innovation. Response toward operation environment can be categorized as the strategic orientation of each company. All of this is used as the main means to understand the actions taken by the company in achieving the increase in profitability, financial performance, or competitive advantage (Matsuno, 2015; Bodea \& Dutu, 2016; Huang \& Ngoc, 2019). Many types of strategic orientation are not exclusive because companies in general are involved in several approached at the same time.

MSMEs strategic orientation is expected to have an impact on organizational innovation. It cannot be denied that fast-developing technology and market demand that is more various require MSMEs to innovate in order to win the competition. Companies then compete with each other are innovative in their respective field of business. Related 
to the organizational innovation, there are three innovation components stated by Al-bilbiese and Al-Nuaimi (2017):

(1) administrative innovation, (2) product innovation, and

(3) process innovation. Administrative innovation refers to the provision of all new things in terms of behavior and management performance, and finds new ways to solve problems and apply new ideas. It is intended for management to be brave to launch new ideas for innovation that is needed by the company. Kim et al. (2012), Kurniawati et al. (2018), and Widya-Hasuti et al. (2018) stated that administrative innovation uses a top-down approach where top-level managers are committed to relevant activities. It is because top management is doing the evaluation, and they are potentially suggesting administrative innovation in the company.

Product innovation is the ability to produce product, service, and idea that are useful to achieve productivity and the best performance goal possible for the organization to build dominant a position in a competitive market and better respond to the external environment; it also refers to the change of the end of the supply of products and services (Newbert, 2008). Process innovation is a change in the method of producing products or services with an effort to reduce the production cost (Ardito et al., 2018; Kim et al., 2012; Widya-Hasuti et al., 2018). Beside these three innovations, there is also technology innovation. Technology innovation can be divided into incremental and radical innovation while considering these features: level of change (minor vs major), customer or market target (existing vs new), and level of risk (low vs high). Some empirical studies have proven that strategic orientation will influence organizational innovation and organizational performance (Widya-Hasuti et al., 2018; Obeidat, 2016; Reulink, 2012).

\subsection{Resource Orientation, Organizational Innovation, and MSMEs Performance}

Resource in an organization is a very important asset. The RBV view always emphasizes that the competitive advantage of an organization will be reached in long term if the organization has a valuable resource, rareness, imitability, and non-substitutable (VRIN) (Muafi et al., 2019). Resource includes all assets owned by the organization, such as skills, organization process, owned attributes, information, and knowledge. It can be both tangible and intangible assets that can be managed by the organization (Jang, 2013; Wernerfelt, 1984). In managing resource, the company has to; (1) be able to combine traditional strategy into the unique competence of the company by considering the asset capability of other heterogenic companies, (2) resource must be in accordance with the economic view of the organization, and (3) can be used to analyse research in the organization industry. It means that the company has an opportunity to utilize the resources it owned efficiently and effectively and it can be useful to implement the organization strategy by optimizing the organization research that has an impact on the company performance (Wills-Johnson, 2008; Napitupulu, et al., 2020; Huang \& Ngoc, 2019). Islami et al. (2018) and Napitupulu et al. (2020) stated that research in the future has to include the aspect of external environment turbulence and analyze its impact toward the existence of internal resources owned by the company. It will be a heavy challenge for Batik MSMEs in facing the Industry 4.0. Resources owned by the organization must be utilized optimally by combining the technology owned by the company. Resources must be unique, dynamic, and synergized with each other. Unique means that it cannot be imitated, transferred, and must be rare. It becomes an added value for the organization. Dynamic means that organization resources must integrate, build, and reconfigure the internal and external capabilities of the organization in order to deal with turbulent environmental changes and can have an impact on organizational innovation (Islami et al., 2018; Muafi et al., 2019) and company performance (Islami et al., 2018; Tuan \& Yoshi, 2010; Su et al., 2018; Napitupulu et al., 2020). This result is strengthened by the research from Zaied et al. (2015) that there is an effect between internal and external resources of the company on organizational innovation. This finding is also strengthened by Obeidat's (2016), who emphasized that strategic orientation has an effect toward organizational innovation and has no impact on organizational performance. Internal knowledge can be an important element to proves that has an impact toward organizational innovation, so that the organization can create new design, new product, or even new method (Muafi et al., 2019). The synergy between resources makes the organization able to produce organizational innovation that will have a significant impact on company performance $(\mathrm{Su}$ et al., 2018; Islami et al., 2018).

\subsection{Market Orientation, Organizational Innovation, and MSMEs Performance}

Companies are always required to be able to provide understanding to its customers and to deliver superior value in the eyes of customers in the long term, as well as in Indonesia (Widya-Hasuti et al., 2018). The company will assume that customer's taste is a guideline in running the business. Slater and Narver (1996) also added that market orientation includes three components; customer orientation, competitor orientation, and cross-functional coordination. The company will be able to survive in the long-term when simultaneously carrying out its customer and competitor activities and then coordinate between functions within the organization it manages. 
In customer orientation, company must be able to understand the whole consumer value chain that is being served, especially in the Industry 4.0 era nowadays. Consumers in their development have always been influenced by digital technology that grows rapidly and has no limits. Company must be able to capture these opportunities by looking at current and future needs and desires. Previously, consumers were passive in searching for information. The rapid growth and development of digital technology turned out to have influenced consumers to act and decide to buy products or services quickly, easily, personally, and satisfactorily. The study of Global Digital Operations Study in 2018 published by Pricewaterhouse Cooper (PwC) business consultant proved that companies that successfully transform itself along with the demands of Industry 4.0 will succeed in integrating four important ecosystem components: operation, human resources, technology, and consumer solutions (PwC Strategyand, 2018).

Consumer needs are constantly changing dynamically, especially for consumers who have a wide choice of attractive products and services in this digital era. Therefore, it is also very important for MSME companies to start learning to understand the changing needs and consumer behavior digitally to meet their expectations. MSMEs are required to have the ability to adapt and transform, so that they have the key to face Industry 4.0. Not only in the production process, but also in the entire industrial value chain using new digitally based business models to meet the needs and desires of consumers. Whereas, if the company focuses on a competitor, it means that it must understand the short-term strength and weakness and also the capabilities of the organization. Likewise, it must analyze the long-term marketing strategies of existing and potential competitors. The research result proves that there is a positive relationship between market orientation and organizational innovation (Ashrafi \& Ravasan, 2018; Huhtala et al., 2014), especially SMEs performance (Saunila, 2014).

\subsection{Social Network, Organizational Innovation, and MSMEs Performance}

In MSMEs development, the owners or managers are demanded to have social capital in the form of strong social network. Social network is one of the approaches that can be used to overcome the problem of poverty, health, education, and household economy in the community (Grootaert, \& Bastelar, 2001). MSMEs usually come from the community, by the community, and for the community. They can develop because of social interactions between individuals and institutions in society. More empirical evidence shows that the density of social networks and institutions, and the nature of the underlying interpersonal interactions, will significantly affect the efficiency and sustainability of a program (Grootaert, \& Bastelar, 2001; Leopold, 2017; Aujirpongpan \& Hareebin, 2020). More specifically, the concept of social network is one of the social dimensions beside trust and norms. It includes social relations into cooperation. In principle, social network can be formed because of the motivation of a group of individuals, such as mutual curiosity, crossing in providing information, reminding, and helping in carrying out work to achieve goals (Leopold, 2017). The dissemination of innovation really requires the support of social network, so that it will have an impact on the economic growth of a region (Grootaert, \& Bastelar, 2001). Welman et al. (1997; 2003) added that social network requires principles such as: (1) relationship between actors is reciprocal asymmetry, both in context and intensity, (2) relationship between members are direct and indirect, bonds are defined in the context of structured network, (3) bonds create non-random networks, (4) network groups can lead to the creation of cross relations between network groups and between individuals, and (5) the existence of asymmetrical bonds of complex network systems because limited resources must be distributed. The research result from Cartoni at al. (2013) and Leopold (2017) confirmed that social network in non-formal structure can actually contribute significantly to the diffusion of innovation and knowledge that can be developed and explored. This result is strengthened by the findings from Leenders and Dolfsma (2016) that social networks are basically stratified in four 'levels': networks within the company, networks that cross corporate boundaries, networks between companies, and networks that are outside the company. These networks are very useful for the growth of innovation and development of new products. More specifically, Aryobsei (2015) and Garcia-Morales et al. (2018) stated the importance of information technology in social media network can strengthen the emergence of innovation openly. The research findings from Muller and Perres (2018) explained that the structure of social network can influence market innovation. The growth of innovation is very effective if there are " $3 \mathrm{Cs}$ ": cohesion (strong reciprocal influence among its members), connectedness (high number of bonds), and conciseness (low redundancy).

\subsection{Knowledge Sharing, Organizational Innovation, and MSMEs Performance}

Knowledge sharing is a hard thing to do. This is reasonable, considering that there is tendency for someone to store and accumulate the knowledge they have for their own sake. A survey conducted by Ernst \& Young Center 
for Business Innovation in 431 organizations in the United States and Europe in 1997 concluded that one of the biggest difficulties of knowledge management is changing the behavior of knowledge sharing (Bock \& Kim, 2002). A knowledge sharing behavior means that someone: (1) donates knowledge he owned to others and (2) the recipient of knowledge collects that knowledge. Both processes are influenced by other factors such as technology (Van den Hoff \& de Ridder, 2004). Knowledge sharing can be useful to provide access for someone to relevant information that is received and can be used to build and utilize the knowledge network owned by the organization. A wide individual knowledge network can provide great benefits in increasing organizational effectiveness and efficiency (Hogel et al., 2003). The research result from Hogel et al. (2003) concluded that the perception of work team in the organization is related to the organization climate of knowledge sharing, team network preferences, and perception about the importance of team network for the success of project that positively affects individuals' network building.

Knowledge sharing is a highly recommended behaviour for small organizations such as MSMEs. Organization can grow and have superior performance if they are able to manage their knowledge as scarce knowledge assets and cannot be replicated especially in the digital era of economy (Keszey, 2018). If this condition is achieved, it can be a value added benefit (Liebowitz, 2001) so that it can produce innovation for the organization (Muafi et al., 2019). Charterina and Landeta (2013) and Zaied et al. (2015) emphasize that knowledge sharing will have a significant positive effect toward organizational innovation. Knowledge sharing in organizational learning can be a unique asset in the increase of organizational innovation, especially in the relationship of suppliercustomer. Individual learners are individuals who exchange knowledge between one another (Connelly \& Kelloway (2003), where they will be able to generate new ideas in developing organizational innovation (Mehrabani, 2012). It is also added by Zohoori et al. (2013) and Podrug et al. (2017) that in sharing knowledge both tacit and explicit will have a positive impact and increase innovation speed and innovation quality. The initiation of innovation has a dependence on work experience, expertise, and knowledge of employees in the process of creating value for the company. Organizations that are always innovative will be able to produce organizational performance well (Podrug et al., 2017; Lee \& Xuan, 2019).

\subsection{Hypotheses}

H1. Resource Orientation (RES_O) has a significant effect on Organizational Innovation (ORG_INNOV)
H2. Market Orientation (MAR O) has a significant effect on Organizational Innovation (ORG_INNOV)

H3. Social Network (SN) has a significant effect on Organizational Innovation (ORG_INNOV)

H4. Knowledge Sharing (KS) has a significant effect on Organizational Innovation (ORG_INNOV)

H5. Resource Orientation (RES_O) has a significant effect on MSMEs Performance (FS).

H6. Market Orientation (MAR O) has a significant effect on MSMEs Performance (FS).

H7. Social Network (SN) has a significant effect on MSMEs Performance (FS).

H8. Knowledge Sharing (KS) has a significant effect on MSMEs Performance (FS).

\section{Research Method}

This research is conducted in Batik MSMEs in Pekalongan and Klaten, Central Java, Indonesia. Pekalongan and Klaten have become city of Batik that has been known in the world. The population of this research consists of all MSMEs in Pekalongan and Klaten that have asset between 50 million and 2.5 billion, and annual sales of consecutive amounts of 300 millions to 50 billion. The sample of this research comprises most of the MSMEs spread in Pekalongan City and Klaten Regency with a target sample of 120 respondents chosen purposively. The characteristic of the MSMEs are the one that have been established and operated for at least five years and produce a minimum of two types of batik variants. Some 110 questionnaires were valid and reliable. The scale technique is using 7-point Likert scale, from 7 (very strongly agree) to 1 (very strongly disagree). The statistical technique is using Partial Least Square (PLS). The validity and reliability test result shows that the questionnaire is valid and reliable. The results of Goodness of Fit (GoF) model in this study have also met the requirement. The questionnaire sources from each variable with the item number are as follows:

- Resource Orientation (RES O), modified from Reulink (2012) with six questionnaire items.

- Market Orientation (MAR O), modified from Reulink (2012) with six questionnaire items.

- Social Network (SN), modified from Peslak et al. (2010) with nine questionnaire items.

- Knowledge Sharing (KS), modified from Mulyana et al. (2015) with six questionnaire items.

- Organizational Innovation (ORG_INNOV), adopted and modified from Reulink (2012) with six questionnaire items.

- MSMEs Performance (FS), adopted and modified from Reulink (2012) with four questionnare items. 


\section{Research Result}

\subsection{Respondent and Business Characteristics}

The data processing result show that the majority of respondents are owners of SMEs who also the managers $(80 \%)$, men $(60 \%)$, and still in productive age since most of them are under 40 (70\% are $21-40$ years old) and $60 \%$ have a Senior High School education.

Whereas, the majority of business description obtained are: (1) oriented to local and regional market $(82 \%)$, (2) synthetic dye orientation $(60 \%)$, (3) have assets value of 50-450 million (30\%) and 451-650 million (30\%), (4) have annual sales volume of 300 million to 1 billion (90\%), (5) SMEs are established for 5 to 10 years $(60 \%)$, (6) the batik motifs range from 10 to 15 variants $(50 \%)$ and the motifs include five to ten colors $(80 \%)$. Table 1 shows more details.

\subsection{Research Variable Correlation}

The result in Table 2 shows that the correlation coefficient of some research variables have a quite high score with the significance level below 0,05. This shows that the each variable that is studied has a significant relationship.

\subsection{Inner Model Test and Research Hypothesis}

Inner model or structural model is evaluated by looking at the relationship path coefficient parameter value between latent variables (see Figure 1).

Table 1: Respondents Profile and Business Characteristics

\begin{tabular}{|c|c|c|c|}
\hline \multicolumn{2}{|c|}{ Respondents Profile } & \multirow{2}{*}{$\begin{array}{c}\text { Frequency } \\
88 \\
22 \\
\end{array}$} & \multirow{2}{*}{$\begin{array}{c}\text { Percentage (\%) } \\
80 \\
20 \\
\end{array}$} \\
\hline Position & $\begin{array}{l}\text { Owner and Manager } \\
\text { Manager }\end{array}$ & & \\
\hline Gender & $\begin{array}{l}\text { Man } \\
\text { Woman }\end{array}$ & $\begin{array}{l}66 \\
44 \\
\end{array}$ & $\begin{array}{l}60 \\
40 \\
\end{array}$ \\
\hline Age & $\begin{array}{l}21-30 \text { Years Old } \\
31-40 \text { Years Old } \\
>40 \text { Years Old }\end{array}$ & $\begin{array}{l}33 \\
44 \\
33 \\
\end{array}$ & $\begin{array}{l}30 \\
40 \\
30 \\
\end{array}$ \\
\hline Education & $\begin{array}{l}\text { Yunior High Scholl } \\
\text { Senior High School } \\
\text { Bachelor }\end{array}$ & $\begin{array}{l}33 \\
66 \\
11 \\
\end{array}$ & $\begin{array}{l}30 \\
60 \\
10 \\
\end{array}$ \\
\hline Market orientation & $\begin{array}{l}\text { Local/regional } \\
\text { Export }\end{array}$ & $\begin{array}{l}88 \\
22 \\
\end{array}$ & $\begin{array}{l}80 \\
20 \\
\end{array}$ \\
\hline \multicolumn{4}{|c|}{ Business Characteristics } \\
\hline Dyeing orientation & $\begin{array}{l}\text { Synthetic } \\
\text { Natural }\end{array}$ & $\begin{array}{l}66 \\
44 \\
\end{array}$ & $\begin{array}{l}60 \\
40 \\
\end{array}$ \\
\hline Assets owner & $\begin{array}{l}50-450 \text { million } \\
251-650 \text { million } \\
651 \mathrm{M}-1 \text { billion } \\
>1 \mathrm{Mto} 1.4 \mathrm{M} \\
>1.4 \mathrm{M} \text { to } 2.5 \mathrm{M} \\
\end{array}$ & $\begin{array}{l}33 \\
33 \\
22 \\
11 \\
11\end{array}$ & $\begin{array}{l}30 \\
30 \\
20 \\
10 \\
10\end{array}$ \\
\hline Selling Value (IDR) & $\begin{array}{l}300 \mathrm{M} \text { to } 1 \text { billion } \\
>1 \text { billion to } 10 \text { billion }\end{array}$ & $\begin{array}{l}99 \\
11 \\
\end{array}$ & $\begin{array}{l}90 \\
10 \\
\end{array}$ \\
\hline MSMEs Year & $\begin{array}{l}5-10 \text { Years } \\
11-20 \text { Years } \\
20-30 \text { Years } \\
>30 \text { Years } \\
\end{array}$ & $\begin{array}{l}66 \\
22 \\
11 \\
11 \\
\end{array}$ & $\begin{array}{l}60 \\
20 \\
10 \\
10 \\
\end{array}$ \\
\hline Type of Motives & $\begin{array}{l}10 \text { - } 15 \text { Variation } \\
16 \text { - } 20 \text { Variation } \\
>20 \text { Variation }\end{array}$ & $\begin{array}{l}55 \\
33 \\
22 \\
\end{array}$ & $\begin{array}{l}50 \\
30 \\
20 \\
\end{array}$ \\
\hline Color per Motives & $\begin{array}{l}5-10 \text { Color } \\
11-15 \text { Color } \\
>15 \text { Color }\end{array}$ & $\begin{array}{l}88 \\
11 \\
11 \\
\end{array}$ & $\begin{array}{l}80 \\
10 \\
10 \\
\end{array}$ \\
\hline & Amount & 110 & 100,0 \\
\hline
\end{tabular}


Table 2: Zero Order Correlation of Study Variables

\begin{tabular}{|c|c|c|c|c|c|c|}
\hline No. & Variable & 1 & 2 & 3 & 4 & 5 \\
\hline 1 & Resource Orientation (RES O) & 1.000 & & & & \\
\hline 2 & Market Orientation (MAR O) & $0.666^{* *}$ & 1.000 & & & \\
\hline 3 & Social Networking (SN) & $0.478^{* *}$ & $0.428^{* *}$ & 1.000 & & \\
\hline 4 & Knowledge Sharing (KS) & $-0.188^{*}$ & -0.147 & 0.061 & 1.000 & \\
\hline 5 & Organizational Innovation (ORG_INNOV) & $0.743^{* *}$ & $0.682^{* *}$ & $0.602^{* *}$ & -0.121 & 1.000 \\
\hline 6 & MSMEs Performance (FS) & $0.750^{*}$ & $0.729^{* *}$ & $0.717^{* *}$ & -0.165 & $0.801^{* *}$ \\
\hline
\end{tabular}

** $=p<0,01 ;$ two-tiled

$*=p<0,05 ;$ two-tiled

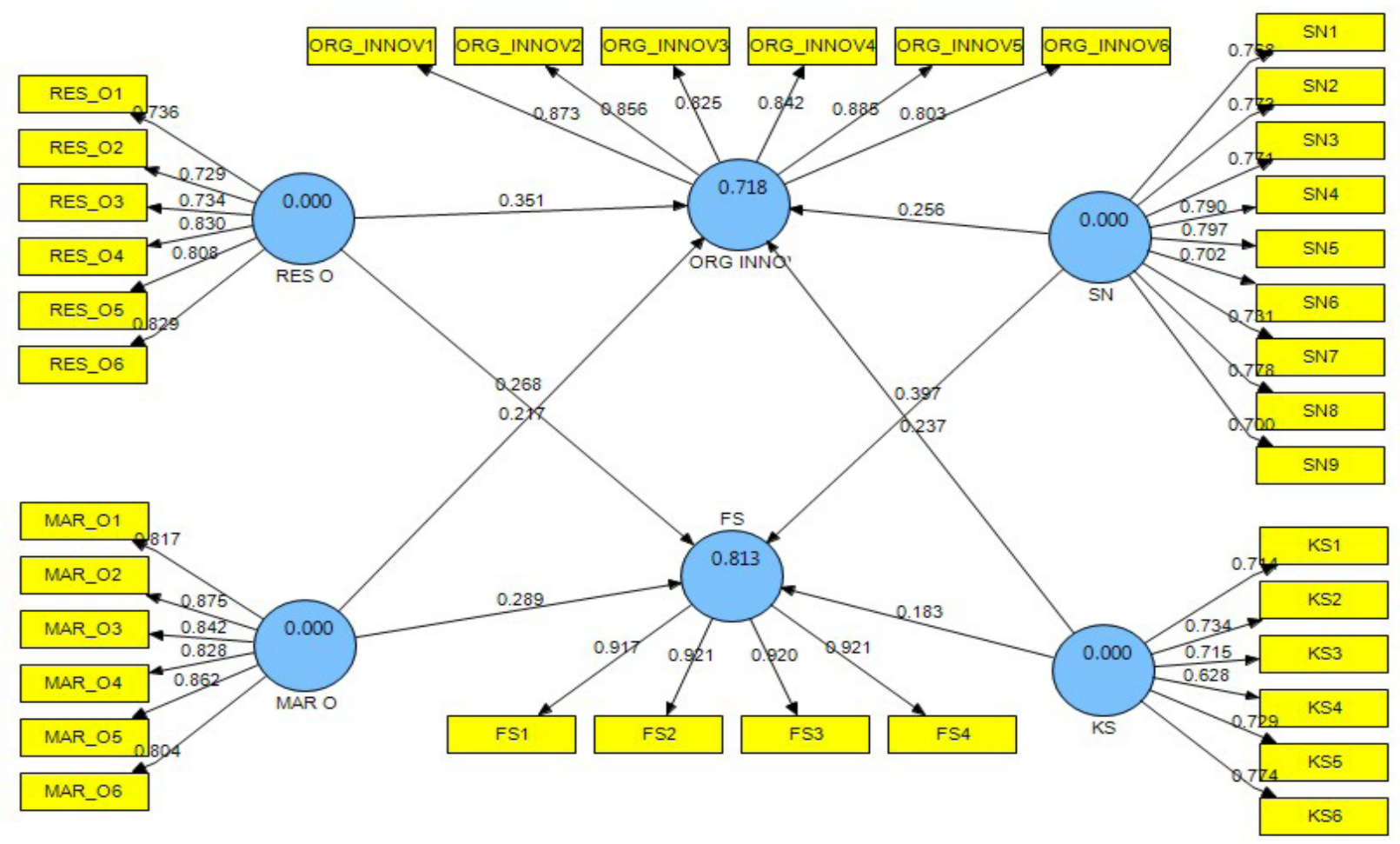

Figure 1: Path Coefficient Diagram and Hypothesis Test

The inner model test result on Table 3 shows that all relationship between inner variables are significant at $\alpha=$ 0,05 . It means that all hypotheses are accepted.

Resource Orientation (RES O) has a significant effect on Organizational Innovation (ORG INNOV) with path coefficient of 0,351 and $t$ value $=5,736$ (the significance of 0,000 which is smaller than $\alpha(0,05)$. This positive coefficient means that the increase of Resource Orientation (RES O) will encourage an increase in Organizational Innovation (ORG INNOV). The first hypothesis is accepted.

Market Orientation (MAR O) has a significant effect on Organizational Innovation (ORG INNOV) with path coefficient of 0,217 and $t$ value $=3,490$ (the significance of 0,001 which is smaller than $\alpha(0,05)$. This positive coefficient means that the increase of Market Orientation (MAR O) will encourage an increase in Organizational Innovation (ORG INNOV). The second hypothesis is accepted.

Social Networking (SN) has a significant effect on Organizational Innovation (ORG INNOV) with path coefficient of 0,256 and $t$ value $=3,858$ (the significance of 0,000 which is smaller than $\alpha(0,05)$. This positive coefficient means that the increase of Social Networking (SN) will encourage an increase in Organizational Innovation (ORG INNOV). The third hypothesis is accepted. 
Table 3: Inner Model Test Result

\begin{tabular}{|c|l|c|c|c|c|c|}
\hline Hypothesis & \multicolumn{1}{|c|}{ Path } & $\begin{array}{c}\text { Original } \\
\text { Sample (O) }\end{array}$ & $\begin{array}{c}\text { Sample } \\
\text { Mean (M) }\end{array}$ & $\begin{array}{c}\text { Standard } \\
\text { Error } \\
\text { (STERR) }\end{array}$ & $\begin{array}{c}\text { T Statistics } \\
\text { (|O/STERR|) }\end{array}$ & Sig. \\
\hline 1 & RES O -> ORG INNOV & 0.351 & 0.349 & 0.064 & 5.459 & 0.000 \\
\hline 2 & MAR O -> ORG INNOV & 0.217 & 0.211 & 0.066 & 3.268 & 0.001 \\
\hline 3 & SN -> ORG INNOV & 0.256 & 0.260 & 0.058 & 4.404 & 0.000 \\
\hline 4 & KS -> ORG INNOV & 0.237 & 0.238 & 0.071 & 3.324 & 0.001 \\
\hline 5 & RES O -> FS & 0.268 & 0.263 & 0.051 & 5.275 & 0.000 \\
\hline 6 & MAR O -> FS & 0.289 & 0.289 & 0.051 & 5.688 & 0.000 \\
\hline 7 & SN -> FS & 0.397 & 0.399 & 0.055 & 7.252 & 0.000 \\
\hline 8 & KS -> FS & 0.183 & 0.188 & 0.060 & 3.041 & 0.003 \\
\hline
\end{tabular}

Knowledge Sharing (KS) has a significant effect on Organizational Innovation (ORG INNOV) with path coefficient of 0,237 and $t$ value $=3,872$ (the significance of 0,000 which is smaller than $\alpha(0,05)$. This positive coefficient means that the increase of Knowledge Sharing (KS) will encourage an increase in Organizational Innovation (OI). The fourth hypothesis is accepted.

Resource Orientation (RES O) has a significant effect on MSMEs Performance (FS) with path coefficient of 0,268 and $t$ value $=4,640$ (the significance of 0,000 which is smaller than $\alpha(0,05)$. This positive coefficient means that the increase of Resource Orientation (RES O) will encourage an increase in MSMEs Performance (FS). The fifth hypothesis is accepted.

Market Orientation (MAR O) has a significant effect on MSMEs Performance (FS) with path coefficient of 0,289 and $\mathrm{t}$ value $=5,822$ (the significance of 0,000 which is smaller than $\alpha(0,05)$. This positive coefficient means that the increase of Market Orientation (MAR O) will encourage an increase in MSMEs Performance (FS). The sixth hypothesis is accepted.

Social Networking (SN) has a significant effect on MSMEs Performance (FS) with path coefficient of 0,397 and $\mathrm{t}$ value $=7,079$ (the significance of 0,000 which is smaller than $\alpha(0,05)$. This positive coefficient means that the increase of Social Networking (SN) will encourage an increase in MSMEs Performance (FS). The seventh hypothesis is accepted.

Knowledge Sharing (KS) has a significant effect on MSMEs Performance (FS) with path coefficient of 0,183 and $\mathrm{t}$ value $=3,138$ (the significance of 0,002 which is smaller than $\alpha(0,05)$. This positive coefficient means that the increase of Knowledge Sharing (KS) will encourage an increase in MSMEs Performance (FS). The eighth hypothesis is accepted.

\section{Discussion}

The research result proves that strategic orientation (resource and market) has an influence toward organizational innovation. MSMEs businessmen are fully aware that today they are required to have a strategy that is right on track, which include resource and market aspects. This result also strengthens the prior research finding that resources orientation (Muafi et al., 2019; Obeidat, 2016; Zaied et al., 2015; Su et al., 2018; Islami et al., 2018) and market orientation (Ashrafi \& Ravasan, 2018) can increase organizational innovation and organizational performance (Saunila, 2014; Aujirpongpan \& Hareebin, 2020; Lee \& Xuan, 2019; Huang \& Ngoc, 2019).

Resource orientation becomes an important requirement because on the production process they need raw materials starting from fabric cutting, mordan (boiling cloth), paper design, pattern design, nyanting, fixation (color locking), and drying, all required resources not easy to implement. However, the production process is still done traditionally and has not use appropriate technology. Human resources aspects also become the key aspect with an important role in each of the activity. On the other hand, after the product is ready to be marketed, they still faced a very high market competition level. Sometimes, they are very irrational because they are competing at the lowest price possible. The important reason is that products are quickly sold and similar products can be produced again. Actually, they feel the need for training and learning related to the business they manage, including the production aspect, marketing, technology, and how to manage their business to be more successful. Government and universities role are required so that they can be smarter in developing their business.

The owner and manager of MSMEs must be able to strengthen social network through many ways. They must be able to connect to other business actors (suppliers, resellers, 
banks, IT companies, universities, NGOs, journalists, community leaders, religious scholars, the government, and other business actors) in order to obtain the resources needed by the organization, and at the same time help to market the product offered at the desired price. Social network has been formed through the existence of an association, which consists of 10 to 20 small batik groups. This association aims to bind members and actively hold useful meetings to: (1) monitor business activities, (2) discuss barriers faced by the groups, (3) discuss product and service innovations that need to meet market tastes, (4) disseminate new innovation in the batik process, ranging from cutting cloth, mordan (cloth boiling), paper design, pattern design, nyanting, fixation (color locking), and drying, (5) set a uniform market price, (6) carry out other positive activities such as preserve the environment, cleanliness, and orderliness in the work area.

This association is family-based and is established by people who aim to foster unity (harmony) among its members. It is hoped that this association will be able to mobilize the resources of the organization so that it can develop the economic potential of the community and increase its productivity so that the natural resources and human resources around the community can be utilized optimally. From this social network, often emerge new innovations from both incremental and radical innovation.

Incremental innovation is usually achieved by making simple changes regarding the existing processes, products, and services. It is done considering the resource heterogeneity owned by each group member. This innovation is accomplished with the purpose to find development and improvement in various activities carried out with consideration of cost efficiency, despite maintaining higher quality of products and services. The improvement in the process, products, and services is done continuously in order to meet batik market tastes. Whereas radical innovation is carried out when there is evidence of the results or ideas that will be carried in the future. This is usually done by collaborating research and community service between the association and universities, supported by the local government. Technological breakouts are carried out, for example, by using appropriate technology in each value chain in the business process, so that it can become the basis for building MSMEs performance, which also can be a competitive advantage for a region.

The use of the right technology will also be able to increase the productivity of an organization and be able to reach consumers more broadly. The radical innovation that is being applied is doing the following: (1) testing the aspect of information technology with mapping of technological context in order to see the capabilities of each component and (2) conducting a trial of value stream mapping (VSM) that is useful for mapping production activities and analyzing value-added activities. The association also expected to be a vehicle for the process of organizational learning for its members to share knowledge. Nevertheless, they also often learn from religious scholars, spiritual teachers, and local community leaders. This is because on average they have spiritual teacher who gives them advice related to manage their business. Knowledge sharing is also obtained by members from the external environment, such as participating in training facilitated by government and stateowned companies in the form of marketing management training, batik production, information technology, coloring technique, and others. It also strengthens the findings from Cartoni (2013; Leopold, 2017) that social network is not only important from the formal structure, but also from nonformal structure.

Innovation will be increasingly widespread and openly available from social media network (Aryobsei, 2015; Garcia-Morales et al., 2018), so that new innovation can emerge (Muller and Perres, 2018). The research result also strengthens some prior research findings that knowledge sharing has a positive and significant influence toward organizational innovation. MSMEs members can exchange knowledge between one another (Connelly \& Kelloway, 2003), in which they will be able to generate new ideas in developing organizational innovation (Mehrabani, 2012) and at the same time can improve innovation speed and innovation quality (Zohoori et al., 2013; Podrug et al., 2017) so that organizational innovation will increase MSMEs performance (Podrug et al., 2017).

The technology also must be efficient in the use of time and cost allocation that will have an impact toward the product that is offered, so that it can be cheaper, but still in a good quality and can compete in domestic and foreign markets. The main capital for MSMEs is to have an efficient and effective business model, starting from upstream to downstream activities, so that they can create products and services that meet the expectation and volatile environment demands. Batik MSMEs in Pekalongan and Klaten must have a good preparation for: (1) ICT in data and content digitalization, (2) flexible manufacturing system where labor collaborates with mechanical engineering process for big and middle scale, (3) e-Smart IKM to widen the market access for MSMEs or small industry, and (4) special competence improvement for employee, besides cyber and physical world that requires labor to be able to analyze the data and assess data bias and quality.

Besides that, Industry 4.0 also demands automatization improvement, machine-to-machine and human-to-machine communication, artificial intelligence, and continuous technological development. It means that the investment needs of Batik MSMEs in Pekalongan and Klaten will be driven by: (1) improvement of data volume, data 
computation, and connectivity; (2) analytical capability and business intelligence; (3) new forms of human-machine interaction, such as touch interface sand augmented-reality system; and (4) development of digital instruction transfer in the physical form, such as robotic and 3D printing. This big challenge requires batik MSME in Pekalongan and Klaten to work hard and smart in developing resources and market they owned optimally and able to strengthen the social network and knowledge sharing between group members in the association. It is hope to increase the organizational innovation that can impact to the improvement of organizational performance in a long term.

\section{Theoretical and Managerial Implication}

This research contributes to strength the theory and science about the need of strategic orientation that is right on target, the strengthen of social network, and knowledge sharing behavior in facing Industry 4.0, so that it can increase organizational innovation and business performance. Strategic orientation in MSMEs management must be directed to resource and market. This research also gives practical implication to the notion that creative MSMEs actors, especially batik, must allocate and optimize the resources they own effectively and efficiently in order to be unique, rare, and valuable. Market orientation is done by noticing customer orientation, competitors, and coordination between functions. This effort is done by noticing the level of competition that occurs outside the company. Social network can be strengthened by establishing good relations through both formal and informal structures with various parties. The culture of knowledge sharing must be accustomed and developed in the long run. MSMEs owners also need to be able to generate knowledge sharing continuously to create an organizational environment and climate that can support the efforts of the improvement of their organizational innovation and organizational performance.

\section{References}

Al-bilbiese, M.E., \& Al-nuaimi, M. (2017). The Impact of Internal Service Quality on Organizational Innovation Examining the Mediating Role of Organizational Commitment: An Empirical Study in the Foreign Banks in Jordan. International Journal of Business and Management, 12(12), 135-143.

Ardito, L., Besson, E., Petruzzelli, A., \& Gregori, G. (2018). The influence of production, IT, and logistics process innovations on ambidexterity performance. Business Process Management Journal, 24(5), 1271-1284.

Aryobsei, S. (2015). How .Social Media Impacts Innovation. Empirical Investigations of Involving the Crowd in New Product Development Processes. Dissertation, The University of St. Gallen, School of Management, Economics, Law, Social
Sciences and International Affairs. https://www1.unisg.ch/ www/edis.nsf/SysLkpByIdentifier/4325/\$FILE/dis4325.pdf.

Ashrafi, A., \& Ravasan, A.Z. (2018). How market orientation contributes to innovation and market performance: the roles of business analytics and flexible IT infrastructure. Journal of Business \& Industrial Marketing, 33(7), 970-983.

Aujirpongpan, S., \& Hareebin, Y. (2020). The Effect of Strategic Intuition, Business Analytic, Networking Capabilities and Dynamic Strategy onInnovation Performance: The Empirical Study Thai Processed Food Exporters. Journal of Asian Finance, Economics and Business, 7(1), 259-268. https://doi. org/10.13106/jafeb.2020.vol7.no1.259.

Bock, G.W., \& Kim, Y. (2002). Breaking the Myths of Rewards: An Exploratory Study of Attitudes about Knowledge Sharing, Information Resources Management Journal, 15(2), 14-21.

Bodea, L.S., \& Dutu, C. (2016). The Consequences Of Strategic Orientation Of The Firm On Business Performance. Management \& Marketing, XIV (2), 188-200.

Cartoni, D., Gardim, N., Caballero, S., \&Silveira, M.A. (2013). Contributions of Social Networking for Innovation. Journal of Technology, Management \& Innovation, 8 (Special Issue ALTEC), p. 184-195.

Cerchione, R., Esposito, E., \& Spadaro, M.R. (2015). The Spread of Knowledge Management in SMEs: A Scenarioin Evolution. Sustainability, 7, 10210-10232.

Chaffee, E.E. (1985). Three Models of Strategy. Academy of Management Review, 10 (1), 89-98.

Charterina. J., \& Landeta, J. (2013). Effects of Knowledge-sharing Routines and Dyad-based Investments on Company Innovation and Performance: An Empirical Study of Spanish Manufacturing Companies. International Journal of Management, 30(1), 2139.

Connellly, C.E., \&, Kelloway, E.K. 2003. Predicors of Employees' Perception of Knowledge Sharing Cultures. Leadership and Organization Development Journal, 24, 294-301.

Espino-Rodríguez, T.F., \& Ramírez-Fierro, J.C. (2018). The Relationship Between Strategic Orientation Dimensions and Hotel Outsourcing and Its Impact on Organizational Performance. An Application in a Tourism Destination. Sustainability, 10, 1769,1-17.

Garcia-Morales, V.J., Martín-Rojas, R., \& Lardón-López, M.E. (2018). Influence of social media technologies on organizational performance through knowledge and innovation. Baltic Journal of Management, 13 (3), 345-367.

Garcia-Pont, C., \& Nohria, N. (2002). Local versus Global Mimetism: the Dynamics of Alliance Formation in the Automobile Industry. Strategic Management Journal, 23(4), 307-321.

Grootaert, C., \& Bastelar, T-V. (2001). Understanding And Measuring Social Capital: A Synthesis of Findings and Recommendations From The Social Capital Initiative, Social Capital Initiative Working Paper No. 24, The World Bank Social Development Family Environmentally and Socially 
Sustainable Development Network, p. 1-31. http://siteresources. worldbank.org/INTSOCIALCAPITAL/Resources/SocialCapital-Initiative-Working-Paper-Series/SCI-WPS-24.pdf.

Hakala, H. (2011). Strategic Orientations in Management Literature: Three Approaches toUnderstanding The Interaction between Market, Technology, Entrepreneurial andLearning Orientations. International Journal of Management Reviews, 13(2), 199-217.

Hertog, P., D., Aa, W., v.d., \& De Jong, M., W. (2010). Capabilities for managing service innovation: towards a conceptual framework. Journal of Service Management, 21 (4), 490-514.

Hogel, M., Parboteeah, K.P., \& Munson, C.L. (2003), Team-level antecedents of individuals' knowledge networks. Decision Sciences, 34 (4), 741-70.

Huang, C. C., \& Ngoc, B. H. (2019). The Relationship between Innovation Capability and Firm's Performance in Electronic Companies, Vietnam. Journal of Asian Finance, Economics and Business, 6(3), 295-304. https://doi.org/10.13106/jafeb.2019. vol6.no3.295

Huhtala, J.P., Sihvonen, A., Frosen, J., \& Tikkanen, H. (2014). Market orientation, innovation capability and business performance: Insights from the global financial crisis,. Baltic Journal of Management, 9(2), April, 134 - 152.

Hussain, I., Qurashi, A., Mujtaba, G., Waseem, M.A., \& Iqbal, Z. (2019). Knowledge management: ARoadmapforinnovation in SMEs'sector of Azad Jammu\& Kashmir. Journal of Global Entrepreneurship Research, 9(9), 1-18.

Isada, F., \& Isada, Y. (2017). An Empirical Study Regarding Radical Innovation, Research and Development Management, and Leadership. Našegospodarstvo/Our Economy, 63(2),2231 .

Islami, X.A., Mulolli, E., \& Mustafa, N. (2018). The Effect of Industrial and Internal Factors to the Firm's Performance. Acta Universitatis Danubius, 14 (5), 154-166.

Jang, S.H. (2013). The Offensive Framework of resource Based View (RBV): Inhibiting Others from Pursuing Their Own Values. Journal of Management and Strategy 4(1), 62 -69.

Keszey, T. (2018). Boundary spanners' knowledge sharing for innovation success in turbulent times. Journal of Knowledge Management, 22 (5), 1061-1081.

Khadka, K., \& Maharjan, S. (2017). Customer satisfaction and Customer Loyalty. Thesis, CENTRIA University Of Applied Sciences, Business Management, November.

Kim, D., Kumar, V. \& Kumar, U. (2012). Relationship between quality management practices and innovation. Journal of Operations Management, 30 (4), 295-315.

Kim, J., \& Lee, J. (2018). The Effect of Network Structure on Performance in South Korea SMEs: The Moderating Effects of Absorptive Capacity. Sustainability, 10, 3174; 1-14.

Kumar, K., Boesso, G., Favotto, F., \& Menini, A. (2012). Strategic Orientation, innovation patterns and performances of SMEs and large companies. Journal of Small Business and Enterprise Development, 19 (1), 132-145.

Kurniawati, A., Samadhi, T.M.A.A., Wiratmadja, I.I., Sunaryo, I., \& Rizana, A.F. (2018). Enhancing Innovation through Knowledge Management: A Systematic Literature Review on Empirical Findings. International Journal of Knowledge Engineering, 4, (1), June, 43-49.

Lee, J.W., \& Xuan, Y. (2019). Effects of Technology and Innovation Management and Total Factor Productivity on the Economic Growth of China. Journal of Asian Finance, Economics and Business, 6(2), 63-73. https://doi.org/10.13106/jafeb.2019. vol6.no2.63

Lee, T., \& Nam, H. (2016). An Empirical Study on the Impact of Individual and Organizational Supply Chain Orientation on Supply Chain Management. The Asian Journal of Shipping and Logistics, 32 (4), December, 249-255.

Leenders, R. T. A. J., \& Dolfsma, W. A. (2016). Social Networks for Innovation and New Product Development. Journal of Product Innovation Management, 33 (2), 123-131.

Leopold, H. (2017). Social Collaboration for Corporate Innovation Management, Dissertation, Lancaster University School of Computing and Communications Lancaster, United Kingdom.

Liebowitz, J. (2001). Knowledge management and its link to artificial intelligence. Expert systems with applications, 20 (1), $1-6$.

Matsuno, K. (2015). The Effects of Environmental Uncertainty and Entrepreneurial Proclivity on Market Orientation Process and Growth Momentum. Kindai Management Review, 3, 36-48.

McKelvey, B. (1975). Guidelines for the Empirical Classification of Organizations. Administrative Science Quarterly, 20 (4), 509-525.

Mehrabani, S. E. (2012). Knowledge Management and Innovation Capacity. Journal of Management Research, 4 (2), 164-177.

Ministry of Cooperatives and SMEs. (2018). Vision, Mission and Motto. Retrieved April 30, 2019 from: https://ppid.depkop. go.id/visi-misi-dan-motto/

Ministry of Industry. (2017, April 18). Industri 4.0 Solusi Peningkatan Daya Saing Indonesia. Retrieved May 10, 2019 from: https://kemenperin.go.id/artikel/17432/Industri4.0-Solusi-Peningkatan-Daya-Saing-Indonesia, $\% 20 \% 20$ Industri\%204.0\%20SolusiPeningkatanDayaSaing\%20 Indonesia

Morgan, R.E., \& Strong, C.A. (1998). Market Orientation and Dimensions of Strategic Orientation. European Journal of Marketing, 32, (11/12), 1051-1073.

Muafi, M., Tabor, J., Wendry, B., Surjanti, J., \& Kusumawati, R.A. (2019). Building organizational Innovation through Strategic Orientation. Qualtiy Access to Success, 20 (s1), January, 543548.

Muller, E., \& Peres, R. (2019). The effect of social networks structure on innovation performance: A review and directions 
for research. International Journal of Research in Marketing, p. 1-17 (In Press).

Mulyana, M., Assegaff, M., \& Wasitowati, W. (2015). Pengaruh Knowledge Donating dan Knowledge Collecting terhadap Innovation Capability Kasus Pengembangan UKM Batik di Provinsi Jawa Tengah-Indonesia. Jurnal Manajemen Teknologi, 14 (3), 247-264.

Napitupulu, S., Primiana, I., Nidar, S. R., Effendy, N., \& Puspitasari, D. M. (2020). The Effect of Management Capabilities in Implementing Good Corporate Governance: A Study from Indonesia Banking Sector. Journal of Asian Finance, Economics and Business, 7(1), 159-165. https://doi. org/10.13106/jafeb.2020.vol7.no1.159

Newbert, S. L. (2008). Value, rareness, competitive advantage, and performance: A conceptual-level empirical investigation of the resource-based view of the firm. Strategic Management Journal, 29 (7), 745-768. https://doi.org/10.1002/smj.686.

Obeidat, B.Y. (2016). The Effect of Strategic Orientation on Organizational Performance: The Mediating Role of Innovation. International Journal. Communications, Network and System Sciences, 9, 478-505.

Peslak, A., Ceccucci, W., \& Sendall, P. (2010). An Empirical Study of Social Networking Behavior Using Diffusion of Innovation Theory. Conference on Applied Information Systems Research (CONISAR). Nashville, TN., 3 (1526), 1-14.

Podrug, N., Filipović, D., \& Kovač, M. (2017). Knowledge sharing and firm innovation capability in Croatian ICT companies. International Journal of Manpower, 38 (4), 632-644.

PwC Strategyand. (2018). Industry 4.0: Global Digital Operations Study 2018. Retrieved February 16, 2019 from: https://www. strategyand.pwc.com/gx/en/insights/industry4-0.html

Reulink, R. B. J. (2012). Strategic orientation and innovation performance at Dutch manufacturing SME's: The overrated role of Market Orientation and Entrepreneurial Orientation(Master's thesis, University of Twente). https://essay.utwente.nl/61589/1/ Master_Thesis_Msc_Roy_Reulink.pdf.

Sakyi-Gyinae, K., \& Holmlund, M. (2018). What Do Business Customers Value? An Empirical Study of Value Propositions in a Servitization Context. Technology Innovation Management Review, 8 (5): 36-43.

Saunila, M, (2014). Innovation capability for SME success: perspectives of financial and operational performance. Journal of Advances in Management Research, 11 (2), 163-175.

Shih, T.Y. (2018). Determinants of Enterprises Radical Innovation and Performance: Insights into Strategic Orientation of Cultural and Creative Enterprises. Sustainability, 10, (1871), 1-22.

Sillanpää, I. (2015). Empirical study of measuring supply chain performance, Benchmarking: An International Journal, 22 (2), 290-308.
Slater, S. F., \& Narver, J.C. (1996). Competitive strategy in the market-focused business. Journal of Market-Focused Management, 1, 159-74.

Su, M., Cheng, K., Chung, S., \& Chen, D. (2018). Innovation capability configuration and its influence on the relationship between perceived innovation requirement and organizational performance. Journal of Manufacturing Technology Management, 29 (8), 1316-1331.

Tuan, N.P., \& Yoshi, T. (2010). Organisational capabilitas, competitive advantage and performance in supporting industries in Vietnam. Asian Academy of Management Journal, 21, January, 15 (1), 1-20.

van den Hoff, B., \& de Ridder, J.A. (2004). Knowledge sharing in context: the influence of organizational commitment, Communication Climate, and CMC use on Knowledge Sharing. Journal of Knowledge Management, 8(6), 117130.

Wellman, B., Salaff, J., Dimitrova, D., Garton, L., Gulia, M., \& Haythornthwaite, C. (2003). Computer Networks as Social Networks: Collaborative Work, Telework, and Virtual Community, November. Annual Review of Sociology, 22(1):213-238.

Wellman, B., Wong, R. Y., Tindall, D., \& Nazer, N. (1997). A decade of network change: Turnover, persistence and stability in personal communities. Social Networks, 19(1), 27-50.

Wernerfelt, B. (1984). A resource-based view of the firm. Strategic Management Journal, 5, pp. 171-180.

Widya-Hasuti, A., Mardani, A., Streimikiene, D., Sharifara, A., \& Cavallaro, F. (2018). The Role of Process Innovation between Firm-Specific Capabilities and Sustainable Innovation in SMEs: Empirical Evidence from Indonesia. Sustainability, 10 (7), 2244, 1-26.

Wills-Johnson, N. (2008). The Networked Firm: A Framework for RBV. The Journal of Management Development. 27 (2), 214 -224 .

Wirtz, B.W., \& Daiser, P. (2018). Business Model Development: A Customer-Oriented Perspective. Journal of Business Models, $6(3), 24-44$.

Zaied, R.M.B., Louati, H., \& Affes, H. (2015). The Relationship Between Organizational Innovations, Internal Sources Of Knowledge and Organizational Performance. International Journal of Managing Value and Supply Chains (IJMVSC), 6 (1), March, 53-67.

Zohoori, M., Mohseni, S., Samadi, B., \& Attarnezhad, O. (2013). The relationship between knowledge sharing and innovation in electronic industry of Iran. Interdisiplinary Journal of contemporary Research, 5(1), 722-729. 